Discussion Paper No. 16-060

Does it Pay to Move?

Returns to Regional Mobility at the

Start of the Career for

Tertiary Education Graduates

Michael F. Maier and Maresa Sprietsma

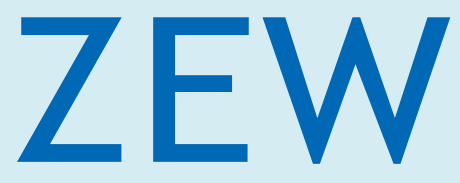

Zentrum für Europäische Wirtschaftsforschung $\mathrm{GmbH}$

Centre for European

Economic Research 
Discussion Paper No. 16-060

\title{
Does it Pay to Move? Returns to Regional Mobility at the Start of the Career for Tertiary Education Graduates
}

\author{
Michael F. Maier and Maresa Sprietsma
}

Download this ZEW Discussion Paper from our ftp server:

http://ftp.zew.de/pub/zew-docs/dp/dp16060.pdf

\begin{abstract}
Die Discussion Papers dienen einer möglichst schnellen Verbreitung von neueren Forschungsarbeiten des ZEW. Die Beiträge liegen in alleiniger Verantwortung der Autoren und stellen nicht notwendigerweise die Meinung des ZEW dar.
\end{abstract}

Discussion Papers are intended to make results of ZEW research promptly available to other economists in order to encourage discussion and suggestions for revisions. The authors are solely responsible for the contents which do not necessarily represent the opinion of the ZEW. 


\title{
Does it Pay to Move? Returns to Regional Mobility at the Start of the Career for Tertiary Education Graduates
}

\author{
Michael F. Maier and Maresa Sprietsma*
}

20th September 2016

\begin{abstract}
Decisions taken at the start of one's career have long-term consequences and one important decision graduates have to make is whether to be regionally mobile when looking for the first job. We investigate whether being regionally mobile for the first job following graduation rather than to stay in the place of graduation pays off. Existing research on regional mobility mostly focuses on job-to-job mobility. We analyse the determinants of early career mobility and estimate a bivariate probit model to account for the dependency between the migration decisions for tertiary education and for the first job. In order to account for self-selection with respect to migration decisions, we exploit variation in the availability of university places at the regional level. Our results show that there is significant dependency between migration decisions made before and after tertiary education. Secondly, using an IV estimation strategy, we find significantly positive wage returns to regional mobility for the first job.
\end{abstract}

JEL Classification: J31, J61

Keywords: regional mobility, wages, university education, early career

Aknowledgements: We would like to thank all participants of the Werkstatt Seminar and the BeNA seminar, as well as Melanie Arntz, Bernd Fitzenberger, Christina Gathmann, Terry Gregory, Laura Pohlan and Verena Wondratschek for their comments and suggestions on earlier versions of the paper. This paper has been written within the DFG Priority Programme SPP1646 "Education as Lifelong Process". Financial support from the German Science Foundation is gratefully acknowlegded. This paper uses data from the National Educational Panel Study (NEPS): Starting Cohort 6 - Adults, doi:10.5157/NEPS:SC6:1.0.0. From 2008 to 2013, NEPS data were collected as part of the Framework Programme for the Promotion of Empirical Educational Research funded by the German Federal Ministry of Education and Research (BMBF). As of 2014, the NEPS survey is carried out by the Leibniz Institute for Educational Trajectories (LIfBi) at the University of Bamberg in cooperation with a nationwide network.

\footnotetext{
${ }^{*}$ Centre for European Economic Research, ZEW Mannheim.
} 


\section{Introduction}

Economic theory predicts that individuals should only be regionally mobile if the returns are higher than the costs (Sjaastad, 1962). Accordingly, most empirical studies find higher monetary returns to job-to-job mobility involving regional mobility as to job changes within a region (e.g. Yankow (2003); Lehmer and Ludsteck (2011)). The costs and benefits of regional mobility decisions taken at the start of the career are different for at least two reasons compared to mobility decisions during the career. First, graduates have not yet developed strong social and professional ties to their place of living and are less likely to have yet started their own family. This implies lower costs of regional mobility and young graduates are therefore more likely to become mobile when entering the labour market than later in their career. Second, whereas individuals deciding on whether to change jobs compare wages and working conditions between the current and potential new jobs, graduates have no information on the current wage level for the comparison with a job offer. They also have less information about their own abilities and job requirements. As a result, graduates take mobility decisions under higher uncertainty than their older counterparts. Thus, individual traits such as risk attitudes and openness to experience could play an important role for the decision to be regionally mobile at the start of the career.

Labour mobility in general is a relevant topic from a policy point of view because it can mitigate regional inequality in economic growth and unemployment (Bonin et al., 2008). The decision to be regionally mobile for the first job is of particular relevance because decisions taken at the start of the career can have lasting effects on labour market success (Topel and Ward, 1992; Baert, 2013; Möller and Umkehrer, 2015). Given the particular situation when entering the labour market, empirical studies on job-to-job mobility cannot answer the question whether it pays off for young graduates to be mobile. We therefore empirically investigate whether tertiary education graduates who are regionally mobile for the first job receive higher wages in the long run than graduates who do not move for the first job.

The analysis focusses on graduates from tertiary education because this group tends to be more mobile than individuals with less education (Machin et al., 2012; Malamud and Wozniak, 2012). Particularly in Germany, mobility patterns differ between graduates from tertiary education and graduates from vocational training. The latter group mostly seeks an apprenticeship in the region where they live and therefore develop stronger ties to the local labour market which in turn determines the location of employment after graduating from an apprenticeship. Furthermore, the importance of social networks and region-specific skills to find a first job are systematically different between the two groups (Fischer et al., 2000; Scherr et al., 2015).

When estimating the effect of mobility on wages unobserved individual traits that jointly influence migration decisions and wages lead to biased results. To obtain an unbiased 
estimate we use two strategies: First, our data provides detailed information on the educational biography which allows us to investigate the determinants of mobility at the start of the career. In particular, we empirically model the dependency between the decision to be regionally mobile for university studies and to be regionally mobile for the first job. This captures an individual's preference to be mobile which is indicated by evidence on the positive correlation between successive mobility decisions (Faggion and Sheppard, 2007; Kidd et al., 2014; Krabel and Floether, 2014) Second, we exploit exogenous variation of the availability of tertiary education places in the county where the individuals graduated from secondary school. The availability of tertiary education places serves as a proxy for an individual's probability to be mobile for tertiary education studies.

We use survey data of tertiary education graduates who entered the German labour market between 1970 and 2000. We focus on the mobility decision for the first job because this mobility decision is rarely revised by further regional mobility. About a third of all graduates in our data (34 percent) are regionally mobile directly after graduation from tertiary education. The majority of graduates remain in the place of first employment for the rest of their careers. 68 percent of the graduates that moved for their first job, as well as 78 percent of the graduates that did not move for their first job, still work in the region where they started their first job at the time of the survey.

Our empirical analysis confirms the dependency between migration decisions in the early career. Individuals who moved for tertiary education have a significantly higher probability of subsequently moving for their first job. Taking into account this previous mobility for tertiary education and exploiting the exogenous variation in the availability of university places we use the predicted probability to be mobile for the first job as an instrument for the actual mobility in a wage regression. The results from instrumental variable regressions show that tertiary education graduates who moved for the first job earn significantly higher wages than those that did not move.

Our paper contributes to the literature which investigates the factors of migration decisions before and at labour market entry (e. g. Krabel and Floether (2014)). Very few studies exist which explicitly analyse the effect of regional mobility at labour market entry on labour market outcomes. ${ }^{1}$ These studies, however do not explicitly model the dependency of migration decisions during schooling until entering the labour market. Similar to our study, Kidd et al. (2014) investigate the wage returns to regional mobility for British graduates accounting for the dependency of migration decisions. None of the studies use exogenous variation to account for the selective of migration decisions throughout the educational period until labour market entry.

The paper is structured as follows. In section 2, we present the data and descriptive

\footnotetext{
${ }^{1}$ di Cintio and Grassi (2013) measure the wage returns accruing from migration to study, migration after graduation and return migration. Winters (2012) analyse the differences in several employment outcomes related to the migration decision of US college graduates. Hensen et al. (2009) and Venhorst and Cörvers (2015), investigate the impact of regional mobility at labour market entry on education-job matches and job match quality, respectively.
} 
statistics of the tertiary education graduates in our sample. The empirical strategy to deal with selective migration decisions of graduates is presented in section 3 and the long-run returns to regional mobility for the first job in section 4 . Section 5 provides robustness checks as well as an interpretation of the results, and the conclusions can be found in section 6 .

\section{Data and descriptive statistics}

To investigate the effect of regional mobility at the start of one's career on current wages, we use the National Education Panel Study (NEPS) data for adults (Blossfeld et al., 2011). This is representative survey data on 25-65 year old individuals collected in Germany in the years 2007-2010. The data contains retrospective information on the educational and professional biography of the survey participants and their place of residence. ${ }^{2}$ The data is organised in education, employment and location spells. Each change in the educational or professional status results in a new spell. Combining this information with information on changes in the place of residence, we construct a biography of an individual's regional location over the course of her education and labour market career.

Our main explanatory variable is regional mobility, which we measure as a binary indicator whether an individual moves from one labour market region (LMR) to another. We measure mobility at two points in one's biography: firstly, when individuals enter tertiary education, and secondly, when they start their first job. The labour market region is a geographical unit defined by the commuting time between two locations being no more than 60 minutes (Eckey et al., 2006). ${ }^{3}$ Our sample includes 150 labour market regions. Our outcome variable is the current hourly net wage, which is computed from monthly net wages and the actual hours worked. Information on wages is only available for the years between 2007 and 2010, when the survey was conducted. Individuals that study in another labour market region but continue to live in their labour market region of origin are not considered mobile according to our definition.

We restrict our sample to graduates from tertiary education which includes universities and applied universities. Furthermore, we include individuals in our sample only if information on their place of residence over time and their hourly net wage is available. This yields a sample where individuals are on average 43 years old, entered the labour market between 1973 and 2009, and have on average 15 years of actual work experience.

In our sample, about one third of the graduates moved for their first job after having graduated from tertiary education (Table 1). 37 percent of the graduates changed the labour market region in order to begin university studies. Second, the figures indicate that individuals who have already moved to begin university are more likely to move for

\footnotetext{
${ }^{2}$ This refers to the actual main place of residence, not the officially registered place of living.

${ }^{3}$ Concerning the aggregation level, the level of regional labour markets is between the NUTS-2 and the NUTS-3 level.
} 
Table 1: Mobility of graduates at the level of labour market regions before and after tertiary education

\begin{tabular}{l|l|l}
\hline & $\begin{array}{l}\text { Share of } \\
\text { graduates } \\
\mathbf{( \% )}\end{array}$ & $\begin{array}{l}\text { No. of Ob- } \\
\text { servations }\end{array}$ \\
\hline Marginal probability of moving & 37.4 & 932 \\
\hline Mobile for tertiary education & 34.5 & 932 \\
\hline Mobile for first job & & \\
\hline Conditional probability of moving for the first & & 348 \\
job & 52.3 & 583 \\
\hline Mobile for first job if mobile for tertiary education & 23.8 & \\
Mobile for first job if not mobile for tertiary education &
\end{tabular}

their first job. The joint probability of being mobile to enter university and to start one's first job is higher than the probability of moving for one's first job if individuals had not previously changed the labour market region to start university.

Movers are likely to be a selective group of tertiary education graduates. Table 2 presents the differences in characteristics between the groups of mobile and immobile individuals at end of secondary education. Mobility rates are higher among females. This confirms existing evidence (e. g. Faggion and Sheppard (2007)). Individuals living in Eastern Germany tend to be more mobile for the first job compared to individuals living in West Germany. This can potentially be explained by the lower regional coverage of universities in the former German Democratic Republic (GDR). The average age of movers and stayers differs by only some months but the difference is statistically significant. Individuals who move either to begin university or for their first job are older than stayers. Rainer and Siedler (2009) find that individuals with more siblings are more mobile. They argue that having a sibling reduces the constraint of taking care of the parents and reduces barriers to mobility. We confirm this finding in our sample.

Table 3 shows comparative statistics for graduates that are mobile or not at the end of tertiary education. We consider the population in the labour market region where individuals obtain tertiary education as a proxy for the thickness of the local labour market. Graduates' choice to be mobile for their first job might reflect the fact that local labour markets cannot absorb all individuals who have graduated in that region. Yet we do not find differences in the average population between labour market regions from which individuals move for their first job and labour market region in which individuals stay to start their first job. We also do not find evidence that mobility rates are related to business cycles or to any other time effects as there are no differences between movers and stayers in their average graduation year.

The probability of being mobile for a first job could also be related to the type of tertiary education obtained. We observe that individuals who graduate from an applied university are less mobile. The decision to be mobile for university studies also depends on the 
Table 2: Descriptive statistics by regional mobility to start tertiary education

\begin{tabular}{|c|c|c|c|}
\hline $\begin{array}{l}\text { Mobility at the level of the } \\
\text { regional labour market }\end{array}$ & Mobile & $\begin{array}{c}\text { Not } \\
\text { Mobile }\end{array}$ & $\begin{array}{l}\text { Test of } \\
\text { Significance }\end{array}$ \\
\hline Male & $\begin{array}{c}0.48 \\
(0.03)\end{array}$ & $\begin{array}{c}0.60 \\
(0.02)\end{array}$ & $* * *$ \\
\hline No sibling & $\begin{array}{c}0.12 \\
(0.02)\end{array}$ & $\begin{array}{c}0.18 \\
(0.03)\end{array}$ & $* * *$ \\
\hline One sibling & $\begin{array}{c}0.39 \\
(0.03)\end{array}$ & $\begin{array}{c}0.44 \\
(0.02)\end{array}$ & * \\
\hline Two or more siblings & $\begin{array}{c}0.47 \\
(0.03)\end{array}$ & $\begin{array}{c}0.38 \\
(0.02)\end{array}$ & $* * *$ \\
\hline Went to school in West Germany & $\begin{array}{c}0.85 \\
(0.02)\end{array}$ & $\begin{array}{c}0.84 \\
(0.02)\end{array}$ & \\
\hline Age at end of secondary school & $\begin{array}{c}19.2 \\
(0.06)\end{array}$ & $\begin{array}{c}18.8 \\
(0.06)\end{array}$ & $* * *$ \\
\hline Major: Science & $\begin{array}{c}0.38 \\
(0.03)\end{array}$ & $\begin{array}{c}0.41 \\
(0.02)\end{array}$ & \\
\hline Major: Teaching & $\begin{array}{c}0.21 \\
(0.02)\end{array}$ & $\begin{array}{c}0.11 \\
(0.01)\end{array}$ & $* * *$ \\
\hline Major: Legal and Social & $\begin{array}{c}0.26 \\
(0.02)\end{array}$ & $\begin{array}{c}0.18 \\
(0.02)\end{array}$ & $* * *$ \\
\hline Major: Business Administration & $\begin{array}{c}0.06 \\
(0.01)\end{array}$ & $\begin{array}{c}0.17 \\
(0.02)\end{array}$ & $* * *$ \\
\hline No. of observations & 348 & 583 & \\
\hline
\end{tabular}

Note: Standard errors are indicated in brackets. ${ }^{* * *},{ }^{* *},{ }^{*}$ stand for statistical significance of the difference at the 1,5 and $10 \%$ level respectively. 
chosen major. However, we find almost no heterogeneity between movers and stayers when entering the labour market regarding the major in which they have graduated. The relative demand at the regional level for a certain university major thus does not play a role for the mobility decision for the first job.

Finally, we capture selective mobility after university graduation by observing individual characteristics. First, the duration of studies can serve as a proxy for the student's ability. We find that movers for the first job on average studied longer than stayers. The average final grade of tertiary education - as another proxy for ability - does not differ between movers and stayers. Moreover, the share of individuals who have been abroad during tertiary education for at least one month, which might result in greater openness towards moving, is the same among movers and stayers.

The lowest section in Table 3 shows whether the search and matching process when transitioning from university to the labour market differs between movers and stayers. We find that it takes movers and stayers the same time to start their first job after graduation from tertiary education. ${ }^{4}$ Tentatively, one can conclude that the possibilities to find a job is the same for those moving and staying in the current place of residence or that searching for a job in an area within the current labour market region or outside takes the same time. Having found their first job, however, movers remain with their first employer for a longer time. This indicates that their first job is a better match (Shaw and Lazear, 2008). If movers do not restrict search for their first job to the local labour market, they are more likely to find a job which better matches their qualification and skill profile thus resulting in a longer tenure.

We observe small differences in labour market outcomes by regional mobility. Movers for the first job accumulate some more actual years of experience, but are on average equally likely to be overqualified as stayers. Overqualification is measured as having a degree superior to that usually required to perform the current occupation. The raw difference in hourly wages shows that stayers earn on average more than movers.

\footnotetext{
${ }^{4}$ The average time between graduation and first job is one year. This may seem quite long but this is related to the long tail of the distribution. $\mathrm{x} \%$ of graduates find their first job within 6 months.
} 
Table 3: Descriptive statistics by regional mobility after graduation

\begin{tabular}{|c|c|c|c|}
\hline $\begin{array}{l}\text { Mobility at the level of } \\
\text { regional labour markets }\end{array}$ & Mobile & $\begin{array}{c}\text { Not } \\
\text { Mobile }\end{array}$ & $\begin{array}{l}\text { Test of } \\
\text { Significance }\end{array}$ \\
\hline Male & $\begin{array}{c}0.51 \\
(0.03)\end{array}$ & $\begin{array}{c}0.58 \\
(0.02)\end{array}$ & $* *$ \\
\hline Major: Science & $\begin{array}{c}0.42 \\
(0.03)\end{array}$ & $\begin{array}{c}0.39 \\
(0.02)\end{array}$ & \\
\hline Major: Teaching & $\begin{array}{c}0.16 \\
(0.02)\end{array}$ & $\begin{array}{c}0.14 \\
(0.01)\end{array}$ & \\
\hline Major: Legal and Social & $\begin{array}{c}0.22 \\
(0.02)\end{array}$ & $\begin{array}{c}0.20 \\
(0.02)\end{array}$ & \\
\hline Major: Business Administration & $\begin{array}{c}0.09 \\
(0.02)\end{array}$ & $\begin{array}{c}0.14 \\
(0.01)\end{array}$ & $* *$ \\
\hline Major:other subject & $\begin{array}{c}0.16 \\
(0.02)\end{array}$ & $\begin{array}{c}0.15 \\
(0.01)\end{array}$ & \\
\hline $\begin{array}{l}\text { Tertiary education in West } \\
\text { Germany }\end{array}$ & $\begin{array}{c}0.73 \\
(0.02)\end{array}$ & $\begin{array}{c}0.80 \\
(0.02)\end{array}$ & $* *$ \\
\hline Age at end of tertiary education & $\begin{array}{c}25.0 \\
(0.18)\end{array}$ & $\begin{array}{c}24.6 \\
(0.14)\end{array}$ & $* *$ \\
\hline Graduated from applied university & $\begin{array}{c}0.29 \\
(0.03)\end{array}$ & $\begin{array}{c}0.40 \\
(0.02)\end{array}$ & $* * *$ \\
\hline Has been abroad during studies & $\begin{array}{c}0.10 \\
(0.02)\end{array}$ & $\begin{array}{c}0.10 \\
(0.01)\end{array}$ & \\
\hline Duration of studies (months) & $\begin{array}{c}64.2 \\
(1.52)\end{array}$ & $\begin{array}{c}59.8 \\
(1.15)\end{array}$ & $* *$ \\
\hline Final grade tertiary education & $\begin{array}{c}2.08 \\
(0.03)\end{array}$ & $\begin{array}{c}2.07 \\
(0.02)\end{array}$ & \\
\hline Graduation year & $\begin{array}{c}1991 \\
(0.48)\end{array}$ & $\begin{array}{l}1992 \\
(0.36)\end{array}$ & \\
\hline $\begin{array}{l}\text { Number of inhabitants in regional } \\
\text { labour market of tertiary } \\
\text { education (thousands) }\end{array}$ & $\begin{array}{c}2920.0 \\
(281.00)\end{array}$ & $\begin{array}{l}1637.3 \\
(49.27)\end{array}$ & \\
\hline $\begin{array}{l}\text { Time between graduation and first } \\
\text { job in months }\end{array}$ & $\begin{array}{c}16.3 \\
(1.73)\end{array}$ & $\begin{array}{c}14.5 \\
(1.37)\end{array}$ & \\
\hline Tenure in first job in months & $\begin{array}{c}64.9 \\
(4.71)\end{array}$ & $\begin{array}{c}51.9 \\
(2.85)\end{array}$ & $* * *$ \\
\hline Current hourly wage in euros & $\begin{array}{c}36.5 \\
(4.33)\end{array}$ & $\begin{array}{c}39.2 \\
(3.15)\end{array}$ & $*$ \\
\hline Experience in years & $\begin{array}{c}16.1 \\
(0.46)\end{array}$ & $\begin{array}{c}15.2 \\
(0.35)\end{array}$ & $*$ \\
\hline Overqualified for current job & $\begin{array}{c}0.17 \\
(0.02)\end{array}$ & $\begin{array}{c}0.17 \\
(0.02)\end{array}$ & \\
\hline Now living in West Germany & $\begin{array}{c}0.82 \\
(0.02)\end{array}$ & $\begin{array}{c}0.88 \\
(0.01)\end{array}$ & $* *$ \\
\hline No. of observations & 321 & 610 & \\
\hline
\end{tabular}

Note: Standard errors are indicated in brackets. ${ }^{* * *},{ }^{* *},{ }^{*}$ stand for statistical significance of the difference at the 1,5 and $10 \%$ level respectively. 


\section{Empirical strategy}

The following section describes the empirical strategy which consists of two parts. Ultimately, we are interested in the effect of regional mobility for the first job on the current wage level. Estimating this effect entails an identification problem which we solve by an instrumental variable method described in section 3.1. In the first stage of the estimation, we use a structural empirical model described in section 3.2 to take into account the dependency of migration decisions.

\subsection{Estimating the wage effect of regional mobility for the first job}

We aim to estimate the effect of regional mobility after graduating from tertiary education on current wages. We use the following wage equation:

$$
\ln \left(w_{i}\right)=\alpha^{w}+\beta^{w} \text { MobileF } J_{i}+\sum \delta^{w} X_{i}^{w}+\varepsilon_{i}
$$

Log hourly wages $\ln \left(w_{i}\right)$ are regressed on $M o b i l e F J_{i}$ which measures whether an individual $i$ has left the labour market region where she graduated from tertiary education for the first job. We are interested in the effect of mobility $\beta^{w}$ on the current wage. $X_{i}^{w}$ is a set of basic control variables including actual working experience, gender, and the current place of residence. $\alpha^{w}$ is the constant of the wage regression.

Graduates that are regionally mobile at the end of tertiary education can be expected to have different characteristics than graduates that do not move. These characteristics are partly unobserved by the researcher. On the one hand, mobile graduates may on average be more open to new experiences and be more active in searching for job offers, which may in turn be considered to indicate a greater level of motivation in finding an adequate first job. On the other hand, immobile graduates may be more able and therefore have better job opportunities in the local labour market than graduates who moved for their first job. It is very likely that individual characteristics such as motivation or ability correlate with current wage levels. If this is the case, we face an endogeneity issue when estimating equation (1) by OLS. The indicator for mobility correlates with the error term $\varepsilon_{i}$ and thus the estimated effect $\hat{\beta^{w}}$ is biased. The direction of the bias is unclear depending on which unobserved effect dominates.

We use the predicted probability of being mobile for the first job as an instrumental variable for actual mobility in a two stage least squares estimation to account for the endogeneity bias. Wooldridge (2010) suggests this procedure (see procedure 21.1). The standard errors and test statistics generated by this estimation procedure are asymptotically valid. The procedure is robust against misspecification of the estimation model from which the probability is predicted. In the following section, we describe how the predicted probability of being mobile for the first job is obtained. 


\subsection{The dependency of migration decisions}

We estimate a bivariate probit model in order to obtain the predicted probability of being mobile for the first job (Heckman, 1978). We use this approach because it allows us to model the dependency between the migration decision when starting tertiary education and the migration decision for the first job. We argue that the migration decision when starting tertiary education is important because it is taken in a formative period of an individual's career. When young people decide whether or not to leave their parents' place of residence, monetary but also psychological costs and benefits may come into play. The psychological costs of moving for the first job should be lower if an individual has already moved before ${ }^{5}$, because it is likely that young people develop a preference for or an aversion to regional mobility at this stage of their biography.

The bivariate probit model consists of two choice equations which are jointly estimated:

$$
\begin{aligned}
& \text { MobileU } S_{i}=\mathbb{1}\left[\gamma^{U S} \# \text { Students } s_{j}+\delta^{U S} X_{i}^{U S}+u_{i}^{U S}>0\right] \\
& \text { MobileF } J_{i}=\mathbb{1}\left[\beta^{F J} \text { MobileU } S_{i}+\delta^{F J} X_{i}^{F J}+u_{i}^{F J}>0\right]
\end{aligned}
$$

Equation (2) models the decision to move to start tertiary education (MobileU $\left.S_{i}\right)$ and equation (3) models the decision to move for the first job (MobileF $\left.J_{i}\right)$ depending on the previous migration decision $\left(M o b i l e U S_{i}\right) . \quad u_{i}^{U S}$ and $u_{i}^{F J}$ reflect unobserved individualspecific utility differences related to each migration decision. The bivariate probit allows for the possibility that both types of mobility are influenced by the same unobserved individual-specific utilities. In that case, the error terms $u_{i}^{U S}$ and $u_{i}^{F J}$ are correlated. Assuming that the error terms $\left(u_{i}^{U S}, u_{i}^{F J}\right)$ are jointly normally distributed, the application of the bivariate probit estimation is more efficient than estimating two separate probit regressions (see Greene (2008) pages 817-822).

$X_{i}^{U S}$ and $X_{i}^{F J}$ include control variables for the migration decisions when entering tertiary education and when moving for the first job, respectively. Control variables are determined before the migration decision is made to model the time structure. This prevents including variables on the right side of the equation which represent choices that are made jointly (i.e. simultaneously) with the dependent variable. In the estimation model for mobility when starting tertiary education, $X_{i}^{U S}$ includes sex, the number of siblings, age on leaving secondary school and an indicator for the region where the individual attended secondary school (West vs. East). In the estimation model for mobility for the first job, $X_{i}^{F J}$ includes sex, the age at graduation from tertiary education, the type of tertiary education (university vs. applied university) and the major subject, when (before or after German reunification) and where individuals have graduated from tertiary education (West vs.

\footnotetext{
${ }^{5}$ Krabel and Floether (2014), Faggion et al. (2007) and Kidd et al. (2014), for example, show that successive migration decisions are correlated.
} 
East), whether they have been abroad for at least one month during their studies, the final grade and the population size in the labour market region where they study.

We consider the migration decision when entering tertiary education to be a treatment variable and the migration decision for the first job as the outcome. However, the decision to be mobile upon entering tertiary education is also related to unobserved student characteristics. Factors such as openness to new experiences or better monetary support and endorsement by parents are likely to affect the mobility decision. We therefore exploit the number of tertiary education students in the labour market region of secondary school at the time of graduation as source of exogenous variation in geographic mobility. This variable is thus excluded from the outcome equation (Equation 3). ${ }^{6}$ The identifying assumption for measuring the average causal effect of the decision to be mobile when starting university studies is that the number of students in the labour market region at the time of finishing secondary education is independent of the unobserved determinants of mobility. To put it differently, the variation in the number of students in the labour market region at the time of leaving secondary education affects the probability of being mobile for the first job only through the migration decision when starting tertiary education. $\beta^{U S}$ can then be interpreted as the average causal effect of the decision to be mobile to start university studies on the probability of moving for the first job. ${ }^{7}$

The number of tertiary education students in the labour market region at the time of leaving secondary education serves as a proxy for the possibility of starting university without moving. If there are very few possibilities to study in the labour market region when finishing secondary school, we expect this to be a strong incentive for potential students to move. Thus, the number of tertiary education students in the labour market region at the time of finishing secondary education is expected to be negatively correlated with moving away to study. This is because young people are more likely to find an adequate possibility to study in the labour market region and thus have fewer reasons to move.

Figure 1 in the appendix depicts the variation in tertiary education places across labour market regions. In the sixties and seventies the majority of labour market regions did not offer places to study. In 1990 still some labour market regions did not provide tertiary education places. Unfortunately, there are no other regional characteristics available at

\footnotetext{
${ }^{6}$ We use information on the number of tertiary education students by labour market region over the years from 1960 to 2008 are taken from the Federal Statistical Office (Statistisches Bundesamt, 2010; Staatsverlag der Deutschen Demokratischen Republik, Berlin, 1975), and from Leszczensky and Filaterow (1990) for Eastern Germany before the reunification of Germany in 1989. Information before 1980 was not available in digital form and was coded from archive publications of the Federal Statistical Office (Statistisches Bundesamt, 1990) based on the number of tertiary education students by higher education institution.

${ }^{7}$ Evans and Schwab (1995), for example, use a bivariate probit model to estimate the average causal effect of attending a Catholic school on the probability of finishing high school and starting college. Angrist (2001) discusses the alternative application of 2SLS estimation in the case of limited dependent variable models with dummy endogenous regressors. We choose the bivariate probit model, as we are primarily interested in the prediction of the probability of being mobile for the first job which serves as an instrument in the wage regression.
} 
the level of labour market regions before 1980. It is therefore not possible to investigate how the characteristics of the counties to which students move to, compare with those of their counties of origin.

Jointly estimating Equations (2) and (3) we obtain the predicted marginal probability $\hat{G}_{i}$ to move for the first job. We use the prediction as an instrument for actual mobility for the first job in the wage equation (Equation (1)):

$$
\hat{G}_{i}=P\left(\text { mobileF } J_{i}=1 \mid \widehat{\# \text { Students }}{ }_{j}, X_{i}^{U S}, X_{i}^{F J}\right)
$$

$\hat{G}_{i}$ is a function of the exogenous variable of the number of tertiary education students in the place of secondary education (\#Students $s_{j}$ ) to proxy the endogenous variable of moving for university studies: $\hat{G}_{i}$ can therefore be considered as a reduced form prediction which does not include the part of mobility which is related to unobserved individual characteristics.

\section{Results}

This section presents the empirical results in two parts. In the first part, we investigate the dependency between the migration decisions for tertiary education and for the first job using a bivariate probit model. We exploit exogenous variation at the regional level in order to infer the causal relevance of the migration decision when starting university studies on the subsequent probability of being mobile for the first job. In the second part, we present the causal effect of the migration decision for the first job on wage levels using the predicted probability of being mobile for the first job as an instrumental variable.

\subsection{The likelihood of being mobile for the first job}

Tables 4 and 5 present the results on the dependency between the migration decisions for tertiary education and for the first job from the bivariate probit model. The upper section of the table displays the determinants of the first migration decision (for tertiary education) and the lower section, the determinants of the second migration decision (for the first job).

As a first main result, we find that the number of students in the labour market region when finishing secondary education is significantly negatively correlated with the probability of being mobile for tertiary education. This means that the fewer university places are available in an individual's labour market region when finishing secondary school, the more likely it is that he or she will move to start tertiary education. ${ }^{8}$ We include an additional variable to indicate that there is no tertiary education institution in the labour

\footnotetext{
${ }^{8}$ This result is also valid for individuals living in Eastern Germany before reunification. In the German Democratic Republic, individuals were assigned to a place of study and to their subsequent workplace for
} 
Table 4: Bivariate probit model to predict the probability of moving after secondary school

\begin{tabular}{|c|c|c|}
\hline $\begin{array}{l}\text { DV: Mobile at the end of secondary } \\
\text { education (LMR level) }\end{array}$ & Coeff. (Std. Error) & $\begin{array}{c}\text { Marginal Effect (Std. } \\
\text { Error) }\end{array}$ \\
\hline $\begin{array}{l}\text { Number of tertiary education students in } \\
\text { LMR of secondary school in year of starting } \\
\text { tertiary education / } 100.000\end{array}$ & $\begin{array}{c}-1.28^{* * *} \\
(0.18)\end{array}$ & $\begin{array}{c}-0.41^{* * *} \\
(0.05)\end{array}$ \\
\hline $\begin{array}{l}\text { No institution of tertiary education in LMR } \\
\text { of secondary school in year of starting } \\
\text { tertiary education }\end{array}$ & $\begin{array}{c}0.54^{* * *} \\
(0.14)\end{array}$ & $\begin{array}{c}0.17^{* * * *} \\
(0.04)\end{array}$ \\
\hline Female & $\begin{array}{l}0.36^{* *} \\
(0.09)\end{array}$ & $\begin{array}{c}0.11^{* * *} \\
(0.03)\end{array}$ \\
\hline Indicator for having one sibling & $\begin{array}{c}0.12 \\
(0.13)\end{array}$ & $\begin{array}{c}0.04 \\
(0.04)\end{array}$ \\
\hline Indicator for having two or more siblings & $\begin{array}{c}0.34^{* * *} \\
(0.13)\end{array}$ & $\begin{array}{l}0.11^{* *} \\
(0.04)\end{array}$ \\
\hline Age at graduation from secondary school & $\begin{array}{c}0.25^{* * *} \\
(0.04)\end{array}$ & $\begin{array}{c}0.08^{* * *} \\
(0.01)\end{array}$ \\
\hline $\begin{array}{l}\text { Attended secondary education in West } \\
\text { Germany }\end{array}$ & $\begin{array}{l}-0.22^{*} \\
(0.11)\end{array}$ & $\begin{array}{l}-0.07^{*} \\
(0.04)\end{array}$ \\
\hline $\begin{array}{l}\text { Attended secondary education after German } \\
\text { reunification }\end{array}$ & $\begin{array}{c}0.04 \\
(0.10)\end{array}$ & $\begin{array}{c}0.01 \\
(0.03)\end{array}$ \\
\hline Constant & $\begin{array}{c}-4.16^{* * *} \\
(0.68)\end{array}$ & - \\
\hline
\end{tabular}

Note: Robust standard errors are reported in brackets. $* * *, * *, *$ stand for statistical significance at the 1,5 and $10 \%$ level respectively.

market region at the time of leaving secondary school. When there is no tertiary education institution in an individual's labour market region at the time of leaving secondary school, she is compelled to be mobile in order to start studying. As a second result, we find strong evidence that the migration decision for the first job is causally related to the migration decision when starting tertiary education. Individuals are more likely to leave the labour market region for the first job if they previously moved to begin tertiary education. ${ }^{9}$

Tables 4 and 5 show that some determinants are only relevant for one of the two migration decisions. Individuals in East Germany are more mobile for tertiary education, before and after German reunification. In contrast, individuals move equally frequently for their first job regardless of whether they were living in East or West Germany at that time. Women are more mobile to start tertiary education than men, while there is no difference concerning the migration decision for the first job. Similarly, age is a relevant factor only for the mobility to start tertiary education. The probability of moving to begin tertiary education increases with age.

political reasons, which might be independant of any geographical considerations. Although individual decisions were thus restricted under the political regime of the GDR, the regional availability of university places still affects the probability to change the labour market region.

${ }^{9}$ The results from a 2 SLS estimation as an alternative to a bivariate probit estimation are similar (see table 11 in the appendix). 
Table 5: cont'd: Bivariate probit model to predict the probability of moving after graduation from tertiary education

\begin{tabular}{|c|c|c|}
\hline DV: Mobile for first job (LMR level) & Coeff. (Std. Error) & $\begin{array}{l}\text { Marginal Effect (Std. } \\
\text { Error) }\end{array}$ \\
\hline Mobile at the end of secondary school & $\begin{array}{c}1.03^{* * *} \\
(0.26)\end{array}$ & $\begin{array}{c}0.32^{* * *} \\
(0.06)\end{array}$ \\
\hline Female & $\begin{array}{c}0.08 \\
(0.10)\end{array}$ & $\begin{array}{c}0.02 \\
(0.03)\end{array}$ \\
\hline Age at graduation from tertiary education & $\begin{array}{l}-0.02 \\
(0.03)\end{array}$ & $\begin{array}{l}-0.00 \\
(0.01)\end{array}$ \\
\hline Graduated from applied university & $\begin{array}{l}-0.16 \\
(0.11)\end{array}$ & $\begin{array}{l}-0.05 \\
(0.03)\end{array}$ \\
\hline Attended tertiary education in West Germany & $\begin{array}{l}-0.13 \\
(0.12)\end{array}$ & $\begin{array}{l}-0.04 \\
(0.04)\end{array}$ \\
\hline $\begin{array}{l}\text { Attended tertiary education after German } \\
\text { reunification }\end{array}$ & $\begin{array}{l}-0.12 \\
(0.10)\end{array}$ & $\begin{array}{l}-0.04 \\
(0.03)\end{array}$ \\
\hline At least one month abroad during studies & $\begin{array}{l}-0.05 \\
(0.15)\end{array}$ & $\begin{array}{c}0.02 \\
(0.05)\end{array}$ \\
\hline Grade tertiary education & $\begin{array}{l}-0.03 \\
(0.08)\end{array}$ & $\begin{array}{l}-0.01 \\
(0.02)\end{array}$ \\
\hline Population in LMR of tertiary education (500 & 0.00 & 0.00 \\
\hline $\begin{array}{l}\text { Population in LMR of tertiary education } \\
(1000000 \text { to } 2000000)\end{array}$ & $\begin{array}{l}-0.13 \\
(0.13)\end{array}$ & $\begin{array}{l}-0.04 \\
(0.04)\end{array}$ \\
\hline $\begin{array}{l}\text { Population in LMR of tertiary education } \\
(2000000 \text { to } 3000000)\end{array}$ & $\begin{array}{c}-0.37 * * * \\
(0.14)\end{array}$ & $\begin{array}{c}-0.11^{* *} \\
(0.04)\end{array}$ \\
\hline $\begin{array}{l}\text { Population in LMR of tertiary education } \\
\text { (more than } 3000000 \text { ) }\end{array}$ & $\begin{array}{c}-0.73^{* * *} \\
(0.21)\end{array}$ & $\begin{array}{c}-0.21^{* * *} \\
(0.05)\end{array}$ \\
\hline Constant & $\begin{array}{l}-0.04 \\
(0.53)\end{array}$ & - \\
\hline Field of study & yes & yes \\
\hline Observations & 931 & 931 \\
\hline$\rho$ & $\begin{array}{l}-0.20 \\
(0.18)\end{array}$ & - \\
\hline Wald chi2(25) & 201.95 & - \\
\hline
\end{tabular}

Note: Robust standard errors are reported in brackets. ${ }^{* * *},{ }^{* *},{ }^{*}$ stand for statistical significance at the 1, 5 and $10 \%$ level respectively. 
Table 6: OLS regression of hourly wages on regional mobility

\begin{tabular}{l|c|c}
\hline Dependent Variable: Log Net & $\begin{array}{c}\text { Without } \\
\text { occupation }\end{array}$ & $\begin{array}{c}\text { With } \\
\text { occupation }\end{array}$ \\
\hline Hourly Wage & 0.01 & -0.00 \\
Fobile for First Job (LMR level) & $(0.05)$ & $(0.05)$ \\
& $-0.29^{* * *}$ & $-0.37^{* * *}$ \\
Found first job in less than one month & $(0.05)$ & $(0.06)$ \\
& 0.00 & 0.02 \\
Experience & $(0.06)$ & $(0.06)$ \\
& $0.03^{* * *}$ & $0.04^{* * *}$ \\
Experience-2/100 & $(0.01)$ & $(0.01)$ \\
& $-0.04^{*}$ & $-0.06^{* *}$ \\
Currently lives in West Germany & $(0.03)$ & $(0.02)$ \\
& $0.38^{* * *}$ & $0.38^{* * *}$ \\
\hline Occupation in current job & $(0.08)$ & $(0.08)$ \\
\hline Observations & no & yes \\
\hline
\end{tabular}

Note: Robust standard errors are reported in brackets. $* * *, * *, *$ stand for statistical significance at the 1, 5 and $10 \%$ level respectively. The dependent variable is the logarithm of hourly net wages.

Finally, we include variables which are relevant only for one of both migration decisions. The probability of moving for tertiary education is significantly higher for individuals who have more than one sibling. The probability of moving for the first job is not related with the fact whether on have attended a university, rather than an applied university. Individuals that graduated from tertiary education in labour market regions with more than 2,000,000 inhabitants are significantly less likely to be mobile for their first job. This is in line with recent findings by Krabel and Floether (2014) who show that German graduates are less likely to leave metropolises.

\subsection{The effect of mobility for the first job on wages}

To measure the effect of mobility for the first job, we use a parsimoniously specified wage equation (Equation 1). Alongside the indicator for mobility, we include gender, the current place of residence, experience and an indicator for the time between graduation from tertiary education and starting the first job. Running an OLS regression (see Table 6 ) we find that mobility for the first job does not correlate with hourly wages. The results for all other variables are as expected. Males, as well as individuals living in West Germany, earn significantly higher wages. The returns to work experience are positive but decreasing. We find no wage heterogeneity related to the time it takes an individual to enter the labour market following graduation. The effect of regional mobility similarly does not change if we account for the current occupation. 
As a next step, we apply a two stage least square (2SLS) estimation using the predicted regional mobility for the first job from the bivariate probit estimation. Table 7 shows the first stage of the estimation. The predicted regional mobility for the first job from the bivariate probit estimation is strongly correlated with actual regional mobility for the first job. We can conclude from the F-value of excluded instruments in both specifications that the instrument is strong.

Table 7: First stage of 2SLS regression: The effect of predicted regional mobility on actual regional mobility after graduation

\begin{tabular}{l|c|c}
\hline $\begin{array}{l}\text { Dependent Variable: p(mobile after } \\
\text { graduation) }\end{array}$ & $\begin{array}{c}\text { Without } \\
\text { occupation }\end{array}$ & $\begin{array}{c}\text { With } \\
\text { occupation }\end{array}$ \\
\hline Predicted mobility after graduation & $0.76^{* * *}$ & $0.76^{* * *}$ \\
Female & $(0.07)$ & $(0.08)$ \\
& 0.02 & 0.04 \\
Found first job in less than one month & $(0.03)$ & $(0.03)$ \\
& $-0.07^{* *}$ & $-0.08^{* *}$ \\
Experience & $(0.03)$ & $(0.03)$ \\
& 0.01 & 0.01 \\
Experience $2 / 100$ & $(0.00)$ & $(0.00)$ \\
& -0.01 & -0.00 \\
Currently lives in West Germany & $(0.01)$ & $(0.01)$ \\
& -0.04 & -0.05 \\
Constant & $(0.04)$ & $(0.04)$ \\
& 0.11 & 0.02 \\
\hline Occupation in current job & $(0.07)$ & $(0.08)$ \\
\hline F-value (excluded instruments) & no & yes \\
\hline Observations & 108.7 & 102.2 \\
\hline
\end{tabular}

Note: Robust standard errors are reported in brackets. ${ }^{* * *},{ }^{* *},{ }^{*}$ stand for statistical significance at the 1, 5 and $10 \%$ level respectively.

Column 1 in Table 8 presents the second stage of the 2SLS estimation. Tertiary education graduates that were regionally mobile for the first job earn significantly higher wages in the long run than those that did not move. The control variables show similar results compared to the OLS regression. Each year of experience yields positive but decreasing wage returns. Working in West Germany yields higher wages and women earn less than men. Finding the first job within one month after graduation is not related to the current wage level.

Interestingly, if we include the current occupation in the 2SLS regression the effect of regional mobility becomes insignificant (column 2 in Table 8). We interpret the result as an indication that the estimated effect of mobility on wages is related to the choice of occupation. Searching for a first job outside the labour market region when studying increases the range of possible occupations. Positive returns to mobility might then be realised through a better occupational match. Note that the effects from the choice of university major has partialled out in the bivariate probit so that estimated effect of 
Table 8: Second stage of 2SLS estimation: The effect of regional mobility after graduation on hourly wages

\begin{tabular}{l|c|c}
\hline Dependent Variable: Log Net & $\begin{array}{c}\text { Without } \\
\text { occupation }\end{array}$ & $\begin{array}{c}\text { With } \\
\text { occupation }\end{array}$ \\
\hline Mourly Wage & $0.46^{* * *}$ & 0.23 \\
Female & $(0.18)$ & $(0.17)$ \\
& $-0.32^{* * *}$ & $-0.39^{* * *}$ \\
Found first job in less than one month & $(0.06)$ & $(0.06)$ \\
& 0.04 & 0.05 \\
Experience & $(0.06)$ & $(0.06)$ \\
& $0.03^{* * *}$ & $0.04^{* * *}$ \\
Experience $2 / 100$ & $(0.01)$ & $(0.01)$ \\
& -0.03 & $-0.06^{* *}$ \\
Currently lives in West Germany & $(0.02)$ & $(0.02)$ \\
& $0.44^{* * *}$ & $0.41^{* * *}$ \\
\hline Occupation current job & $(0.08)$ & $(0.08)$ \\
\hline Observations & no & yes \\
\hline
\end{tabular}

Note: Robust standard errors are reported in brackets. ${ }^{* * *},{ }^{* *},{ }^{*}$ stand for statistical significance at the 1, 5 and $10 \%$ level respectively. The dependent variable is the logarithm of hourly net wages.

mobility on wages is net of the chosen major. This interpretation should, however, be viewed with caution. Looked at more closely, the occupation in the current job can be seen as a bad control (see Angrist and Pischke (2009), chapter 3.2.3, for a discussion). The occupation in the current job is itself a dependent variable generated by the process of occupational choice throughout the career. Including the occupation in the current job as a control variable thus creates a selection bias problem and the effect of regional mobility cannot be interpreted properly anymore.

\section{Robustness checks and interpretation of results}

As a first robustness check, we test whether the effect of regional mobility on wages varies for different groups. We therefore estimate the bivariate probit and the instrumented wage regression accounting for heterogeneity. Firstly, we include an indicator for the case that individuals graduated in Berlin. As a place of study, Berlin is a special case because prior to German reunification, students tended to move to West Berlin in order to avoid military service. Secondly, we conduct our analysis excluding individuals who move for tertiary education and subsequently return home for their first job. The expected return to mobility of those individuals is different, because they can potentially rely on established networks in their home labour market region. The effect of regional mobility for the first job on wages might differ depending on the length of time between entering the labour market and observing the current wage. Thirdly, we therefore estimate the bivariate probit and the wage regression on the base of two more homogeneous samples: firstly, a sample which 
Table 9: 2SLS Regresssions: Robustness checks

\begin{tabular}{l|c|c|c|c}
\hline Dependent Variable: Log Net & $\begin{array}{c}\text { Control for } \\
\text { Berlin } \\
\text { graduates }\end{array}$ & $\begin{array}{c}\text { Without } \\
\text { individuals } \\
\text { returning } \\
\text { home }\end{array}$ & $\begin{array}{c}\text { Individuals } \\
\text { aged 30-50 }\end{array}$ & $\begin{array}{c}\text { Less } \\
\text { experienced } \\
\text { individuals }\end{array}$ \\
\hline Predicted mobility for first job & $0.45^{* * *}$ & $0.57^{* *}$ & $0.65^{* * *}$ & $0.72^{* *}$ \\
Female & $(0.17)$ & $(0.23)$ & $(0.23)$ & $-28)$ \\
Found first job in less than one & $-0.32^{* * *}$ & $-0.31^{* * *}$ & $-0.33^{* * *}$ & $-0.35^{* * *}$ \\
month & $(0.06)$ & $(0.06)$ & $(0.07)$ & $(0.08)$ \\
Experience & 0.04 & 0.07 & $0.14^{*}$ & 0.08 \\
Experience $2 / 100$ & $0.03^{* * *}$ & $0.03^{* * *}$ & $(0.07)$ & $(0.09)$ \\
Currently lives in West Germany & $(0.01)$ & $(0.01)$ & 0.03 & 0.03 \\
& -0.03 & -0.04 & $-0.02)$ & $(0.03)$ \\
\hline Occupation current job & $(0.02)$ & $(0.03)$ & $(0.05)$ & 0.03 \\
\hline F-value (excluded instruments) & $(0.08)$ & $0.42^{* * *}$ & $0.38^{* * *}$ & $0.32^{* *}$ \\
\hline Observations & no & $(0.09)$ & $(0.10)$ & $(0.12)$ \\
\hline Note: Robust standard errors are reported in brackets. $* * * * * *$ stand for statistical significance at the
\end{tabular}

1, 5 and $10 \%$ level respectively. The dependent variable is the logarithm of hourly net wages.

includes only individuals who are between 30 and 50 (prime age workers) and secondly a sample which considers only the less experienced half of the original estimation sample.

Table 9 shows the second stage results for the robustness checks. In each specification the effect of regional mobility for the first job remains significant positive. Accounting for graduates from Berlin does not change the size of the effect of regional mobility on wages. Excluding individuals who return home for the first job increases the size of the effect. Using a sample including only prime age workers, the effect of regional mobility increases as expected. A far higher increase in the effect can be seen if we consider in the estimation only the less experienced half in our sample. This gives a tentative indication that the effect of regional mobility for the first job on wage tapers off with increasing labour market experience.

Our identification strategy exploits regional variation in the availability of university places as an instrument. The number of university places in each labour market region varies over time (see Figure 1). We tried to also exploit this variation to identify the effect of regional mobility on wages. However, our sample is too small to compare individuals in the same labour market region at different points in time endowed with different possibilities to study. In our analysis, we therefore compare the average outcome of movers and stayers pooled over time. One concern could be that the composition with respect to ability (or earnings capacity) of both groups changes over time. University quality, for example, might change over time which leads to changes in the average ability of students. Also, university openings can provide incentives to students to start university education which 
Table 10: Characteristics of stayers and movers by period of finishing secondary education

\begin{tabular}{l|cc|cc}
\hline $\begin{array}{l}\text { Year of } \\
\text { finishing } \\
\text { secondary } \\
\text { education }\end{array}$ & $\begin{array}{c}\text { Average final grade } \\
\text { of tertiary } \\
\text { education }\end{array}$ & \multicolumn{2}{c}{$\begin{array}{c}\text { Duration of } \\
\text { tertiary education }\end{array}$} \\
\hline & Mobile & $\begin{array}{c}\text { Not } \\
\text { mobile }\end{array}$ & Mobile & $\begin{array}{c}\text { Not } \\
\text { mobile }\end{array}$ \\
\hline Before 1980 & 2.12 & 2.20 & $44.3^{* * *}$ & 31.2 \\
& $(0.10)$ & $(0.06)$ & $(2.33)$ & $(1.56)$ \\
$1980-1989$ & 2.18 & 2.12 & $59.1^{* * *}$ & 51.9 \\
& $(0.05)$ & $(0.04)$ & $(1.57)$ & $(1.51)$ \\
$1990-1999$ & 2.06 & 2.00 & $71.8^{*}$ & 66.9 \\
& $(0.06)$ & $(0.05)$ & $(2.80)$ & $(2.26)$ \\
After 2000 & 1.96 & 2.01 & $75.6^{*}$ & 68.5 \\
& $(0.07)$ & $(0.05)$ & $(3.65)$ & $(2.66)$ \\
\hline Number of & 348 & 583 & 348 & 583 \\
observations & & & & \\
\hline
\end{tabular}

Note: Robust standard errors are reported in brackets. ${ }^{* * *},{ }^{* *}, *$ stand for statistical significance at the 1, 5 and $10 \%$ level respectively.

they would not have done if there was no university in their local market region. ${ }^{10} \mathrm{We}$ argue that in the second case the average ability would predominantly change among the stayers, whereas the first example can yield changes in the composition of movers and stayers likewise.

In Table 10 we compare two proxies for the ability of graduates between the groups of stayers and movers by the period they finished secondary education: the average final grade of tertiary education and the duration of tertiary education. These measures are relevant because they especially capture the ability to study at university which determines an individual's earnings capacity later on. As a result, the comparison of the differences between movers and stayers does not change over time. Differences in the final grades are all insignificant, whereas the differences in the duration of tertiary education are significantly higher for mobile graduates over all periods.

Lastly, for the interpration of our results, we can relate to the concept of Local Average Treatment Effects (LATE) set up by Imbens and Angrist (1994). The subpopulation of compliers in our context consists of students who would move for university studies when there was no possibility to study in their labour market region and who would not move when there were university places in their labour market region. ${ }^{11}$ This excludes persons that chose not to enter tertiary education because they would have had to move. Estimating the LATE relies on the assumption of monotonicity. In our context this it ruled out because there are no students who would move if there were university places in

\footnotetext{
${ }^{10}$ Note that we can rule out any changes over time coming from changes in tuition fees. In Germany, tuition fees were abolished in 1970 and only reintroduced in 2005.

${ }^{11}$ The general conclusions from the LATE concept do not change when the instrument is continuous (see Angrist and Imbens (1995)).
} 
their labour market region and who would not move if there were none.

The LATE estimates are only predictive for the group of compliers. From this, two limitations to the interpretation of our results arise. First, the estimated wage difference can only be compared to other studies that use the same instrument. Unfortunately, we are not aware of any study which exploits the regional variation in university places to investigate the effects of mobility for the first job on wages. Second, we cannot infer from the estimated effect the wage gains of individuals who would moved for university studies irrespective of the availability of university places in the labour market region. These could be students who have very high returns from studying at university or students endowed with wealthy family background: Both groups are expected to have a high expected earnings capacity. According to this reasoning, our estimated effect is a lower bound.

\section{Conclusion}

The aim of the paper is twofold. First, we investigate the effect of mobility between secondary school and tertiary education on the mobility decision when entering the labour market. Second, we assess whether being mobile when entering the labour market pays off for tertiary education graduates in Germany. Exploiting exogenous variation we find that the mobility decision when entering the labour market strongly depends on the mobility decision at the start of tertiary education. In addition, we find that being mobile when entering the labour market yields on average a roughly 50 percent higher cumulative wage. The individuals in our sample on average have 15 years of work experience. Thus, graduates who move for the first job gain afterwards on average about 3.1 percent in wages each year. Given our sample size, however, we cannot investigate at which exact point of the labour market career the returns from regional mobility at labour market entry accrue. The higher effect estimated for the younger half of our sample indicates that the returns to mobility for the first job tapers off over time.

The magnitude of the estimated effect is comparable to the returns on job-to-job mobility found in other studies. For Germany, Lehmer and Möller (2008) estimate returns to regional mobility in the magnitude of two to three percent and Lehmer and Ludsteck (2011) in the magnitude of three to four percent. For the US, Yankow (2003) finds returns to regional mobility of about nine percent for high educated individuals with three to four years work experience. Focusing on the early labour market career, Topel and Ward (1992), find cumulative wage gains at job transitions over the first ten years - irrespective whether this entails changes in the location - of 31 percentage points.

Our results show that there are significant individual returns to regional mobility at the start of the career for those graduates that were compelled to move at the end of secondary school. At least two reasons can be proposed why mobile graduates earn higher wages than nonmobile graduates. First, employers have less information on applicants who have just 
graduated compared to workers with some years of labour market experience. Besides educational attainment the employer evaluates the decision to be mobile as a positive signal for motivation or ability. Second, graduates who choose to be mobile for the first job also have a larger scope for searching an adequate job. Thus, being mobile also means having a higher search intensity to find the first job. We have some evidence for the latter channel because the wage gains of movers seem to be correlated with their occupational choice. Our work is therefore related to the debate on insufficient regional mobility in Europe and its role for efficient labour markets. Migration across and within European countries is much lower than within the US. For instance, in 2010 regional mobility within EU member states amounted to only one percent of the population per year as compared with 2.4 percent in the US (Bonin et al., 2008).

The estimated effect of regional mobility from an OLS regression is lower compared to the IV regression which takes the selectivity of the mobility decision into account. This means that mobile university graduates are a negative selection of all university graduates concerning the earnings capacity. As studies usually find that mobile workers are a positively selected group this result is unexpected and needs further investigation in future research. One possible explanation could be that graduates generally perceive moving costs to be high. Highly able graduates can then stay in the region where they graduated from university while less able university graduates have to move for their first job. 


\section{References}

Angrist, J. D. (2001). Estimation of limited dependent variable models with dummy endogneous regressors: Simple strategies for empirical practice. Journal of Business 86 Economic Statistics, 19(1):2-16.

Angrist, J. D. and Imbens, G. W. (1995). Two-stage least squares estimation of average causal effects in models with variable treatment intensity. Journal of the American Statistical Association, 90:430-442.

Angrist, J. D. and Pischke, J. (2009). Mostly harmless econometrics: An empiricist's companion. Princeton University Press.

Baert, S. (2013). Overeducation at the Start of the Career: Stepping Stone or Trap? Labour Economics, 25:123-140.

Blossfeld, H., Rossbach, H., and von Maurice, J. (2011). Education as a Lifelong Process: The German National EducationalPanel Study (NEPS),. Zeitschrift für Erziehungswissenschaft, 14 .

Bonin, H., Eichhorst, W., Florman, C., Hansen, M., Skiöld, L., Stuhler, J., Tatsiramos, K., Thomasen, H., and Zimmermann, K. (2008). Geographic mobility in the European Union: Optimising its economic and social benefits. IZA Research Report, 19.

di Cintio, M. and Grassi, E. (2013). Internal migration and wages of italian university graduates. Papers in Regional Science, 92(1):119-140.

Eckey, H.-F., Kosfeld, R., and Türck, M. (2006). Abgrenzung deutscher Arbeitsmarktregionen. Raumforschung und Raumordnung, 64(4):299-309.

Evans, W. N. and Schwab, R. M. (1995). Finishing High School and Starting College: Do Catholic Schools Make a Difference? The Quarterly Journal of Economics, 110(4):941974.

Faggion, A., McCann, P., and Sheppard, S. (2007). Human Capital, Higher Education and Graduate Migration:An Analysis of Scottish and Welsh Students. Urban Studies, $44: 2511-2528$.

Faggion, A. and Sheppard, P. M. S. (2007). Some Evidence that Women are more Mobile then Men: Gender Differences in U.K. Graduate Migration Behavior. Journal of Regional Science, 47(3):517-539.

Fischer, P. A., Holm, E., Malmberg, G., and Straubhaar, T. (2000). Why do People Stay? Insider Advantages and Immobility. HWWA Discussion Paper, No. 112.

Greene, W. H. (2008). Econometric analysis. Upper Saddle River, New Jersey, sixth edition. 
Heckman, J. J. (1978). Dummy endogenous variables in a simultaneous equation system. Econometrica, 46(6):931-959.

Hensen, M. H., de Vries, R., and Cörvers, F. (2009). The role of geographic mobility in reducing education-job mismatches in the Netherlands. Papers in Regional Science, 88(3):667-682.

Imbens, G. and Angrist, J. (1994). Identication and estimation of local average treatment effects. Econometrica, 62:467-476.

Kidd, M., O'Leary, N., and Sloane, P. (2014). Should I Stay or Should I Go? An Investigation of Graduate Regional Mobility in the UK and its Impact Upon Early Career Earnings. IZA Discussion Paper, 8325.

Krabel, S. and Floether, C. (2014). Here Today, Gone Tomorrow? Regional Labour Mobility of German University Graduates. Regional Studies, 48(10):1609-1627.

Lehmer, F. and Ludsteck, J. (2011). The Returns of Job Mobility and Inter-Regional Migration: Evidence from Germany. Papers in Regional Science, 90(3):549-572.

Lehmer, F. and Möller, J. (2008). Group-specific effects of inter-regional mobility on earnings - A microdata analysis for Germany. Regional Studies, 42(5):657-673.

Leszczensky, M. and Filaterow, B. (1990). Hochschulstudium in der DDR: Statistischer Überblick. HIS Hochschul-Informations-System, Hannover.

Machin, S., Pelkonen, P., and Salvanes, K. G. (2012). Education and Mobility. Journal of the European Economic Association, 10(2):417-450.

Malamud, O. and Wozniak, A. (2012). The Impact of College on Migration - Evidence from the Vietnam Generation. The Journal of Human Resources, 47(4):913-950.

Möller, J. and Umkehrer, M. (2015). Are there long-term earnings scars from youth unemployment in Germany? Jahrbücher für Nationalökonomie und Statistik, 235/4+5:474498.

Rainer, H. and Siedler, T. (2009). O Brother, Where Art Thou? The Effects of Having a Sibling on Geographic Mobility and Labour Market Outcomes. Economica, 76(303):528556.

Scherr, A., Janz, C., and Müller, S. (2015). Diskriminierung in der beruflichen Bildung. Wie migrantische Jugendliche bei der Lehrstellenvergabe benachteiligt werden. Springer VS, Wiesbaden.

Shaw, K. and Lazear, E. P. (2008). Tenure and output. Labour Economics, 15:710-724.

Sjaastad, L. A. (1962). The Costs and Returns of Human Migraton. Journal of Political Economy, 70:80-93. 
Staatsverlag der Deutschen Demokratischen Republik, Berlin (1958-1975). Statistische Jahrbücher der Deutschen Demokratischen Republik. Fachserie.

Statistisches Bundesamt (1960-1990). Statistische Berichte: Hochschulbesuch. Statistisches Bundesamt, Wiesbaden.

Statistisches Bundesamt (1990-2010). Studierende an Hochschulen. Fachserie, 11(4.1).

Topel, R. H. and Ward, M. P. (1992). Job Mobility and the Careers of Young Men. The Quarterly Journal of Economics, 107(2):439-479.

Venhorst, V. and Cörvers, F. (2015). Entry Into the Working Life: Spatial Mobility and Job Match Quality of Higher Education Graduates. Research Memorandum, Maastricht University 2015-03.

Winters, J. V. (2012). Differences in employment outcomes for college town stayers and leavers. IZA Journal of Migration, 1(11).

Wooldridge, J. (2010). Econometric Analysis of Cross-Section and Panel Data. MIT Press, Cambridge, USA.

Yankow, J. J. (2003). Migration, Job Change, and Wage Growth: A New Perspective on the Pecuniary Return to Geographic Mobility. Journal of Regional Science, 43:483-516. 
Figure 1: Variation in the number of tertiary education students across labour market regions
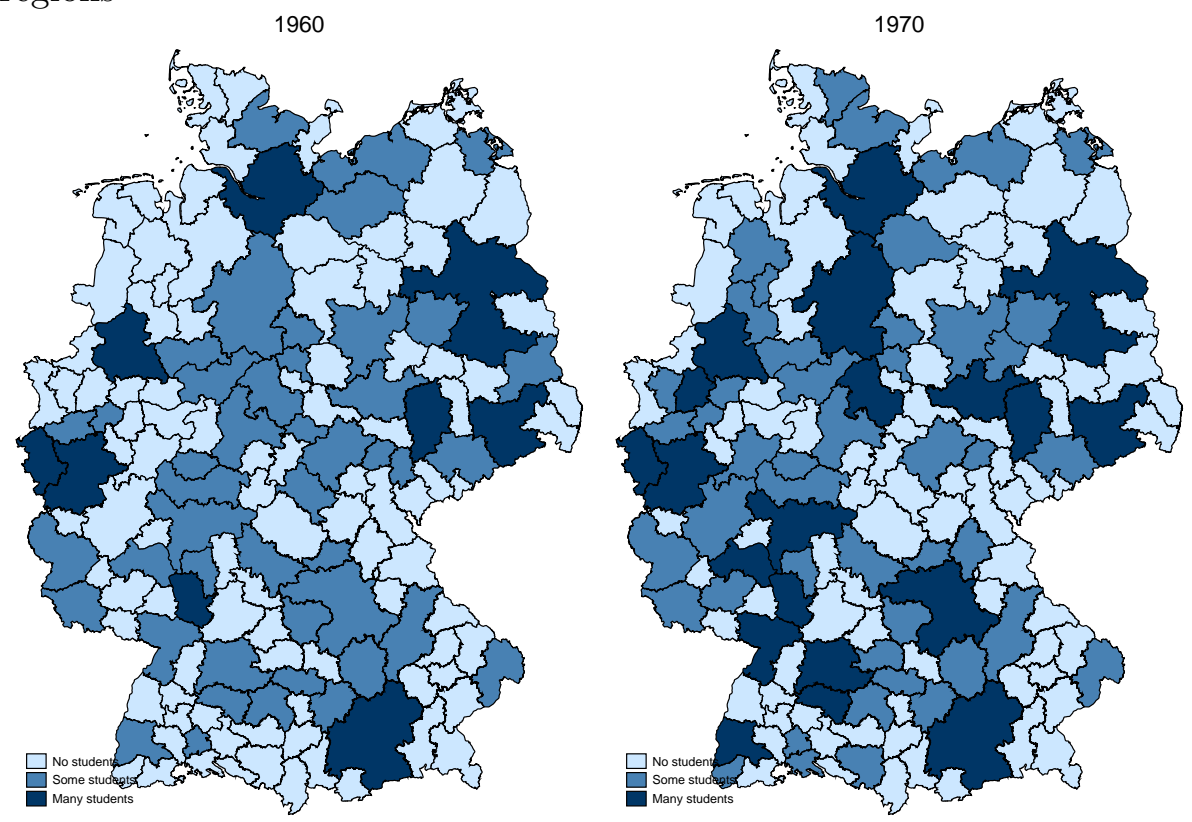

1980
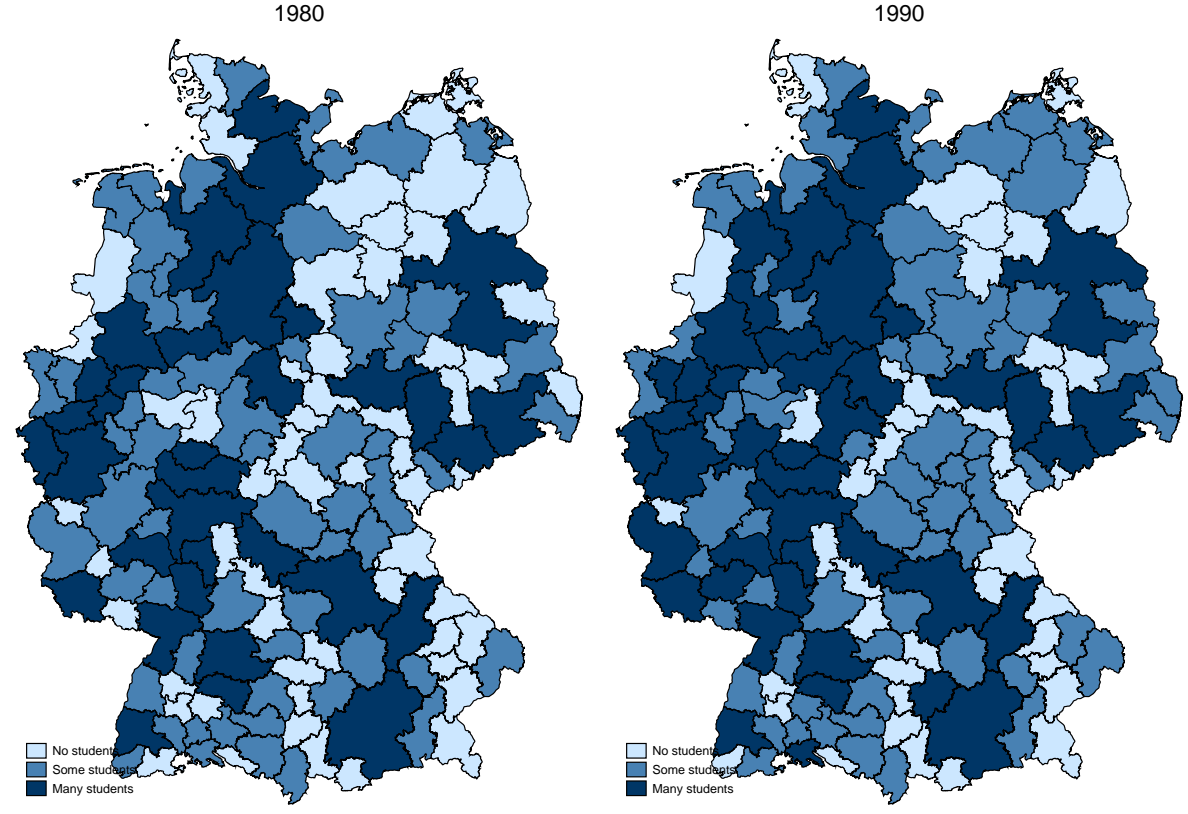

Note: The category "Some students" represents LMRs with up to 10000 students, the category "Many students" LMRs with more than 10000 students. 
Table 11: 2SLS estimation as an alternative to bivariate probit estimation

\begin{tabular}{|c|c|}
\hline Second stage & \\
\hline Mobile for tertiary education & $\begin{array}{c}0.29 * * * \\
(0.11)\end{array}$ \\
\hline Female & $\begin{array}{c}0.04 \\
(0.03)\end{array}$ \\
\hline Indicator for having one sibling & $\begin{array}{l}-0.04 \\
(0.04)\end{array}$ \\
\hline Indicator for having two or more siblings & $\begin{array}{l}-0.03 \\
(0.04)\end{array}$ \\
\hline Age at graduation from secondary education & $\begin{array}{c}0.00 \\
(0.01)\end{array}$ \\
\hline $\begin{array}{l}\text { Attended secondary education in West } \\
\text { Germany }\end{array}$ & $\begin{array}{l}-0.08 \\
(0.09)\end{array}$ \\
\hline $\begin{array}{l}\text { Attended secondary education after German } \\
\text { reunification }\end{array}$ & $\begin{array}{l}-0.02 \\
(0.04)\end{array}$ \\
\hline Age at graduation from tertiary education & $\begin{array}{l}-0.00 \\
(0.00)\end{array}$ \\
\hline Graduated from applied university & $\begin{array}{l}-0.06^{*} \\
(0.04)\end{array}$ \\
\hline Attended tertiary education in West Germany & $\begin{array}{c}0.02 \\
(0.10)\end{array}$ \\
\hline $\begin{array}{l}\text { Attended tertiary education after German } \\
\text { reunification }\end{array}$ & $\begin{array}{l}-0.06 \\
(0.04)\end{array}$ \\
\hline At least one month abroad during studies & $\begin{array}{l}-0.02 \\
(0.05)\end{array}$ \\
\hline Grade tertiary education & $\begin{array}{l}-0.01 \\
(0.03)\end{array}$ \\
\hline $\begin{array}{l}\text { Population in LMR of tertiary } \\
\text { education(500'-1000") }\end{array}$ & $\begin{array}{c}0.00 \\
(0.05)\end{array}$ \\
\hline $\begin{array}{l}\text { Population in LMR of tertiary education } \\
\left(1000^{\prime}-2000^{\prime}\right)\end{array}$ & $\begin{array}{l}-0.05 \\
(0.05)\end{array}$ \\
\hline $\begin{array}{l}\text { Population in LMR of tertiary education } \\
(2000 \text { '-3000") }\end{array}$ & $\begin{array}{c}-0.13^{* * *} \\
(0.05)\end{array}$ \\
\hline $\begin{array}{l}\text { Population in LMR of tertiary education } \\
\left(>3000^{\prime}\right)\end{array}$ & $\begin{array}{c}-0.25^{* * *} \\
(0.06)\end{array}$ \\
\hline Constant & $\begin{array}{c}0.33 \\
(0.23)\end{array}$ \\
\hline Field of study & yes \\
\hline F-value of exluded instruments & 45.4 \\
\hline Observations & 931 \\
\hline
\end{tabular}

Note: Robust standard errors are reported in brackets. ${ }^{* * *},{ }^{* *},{ }^{*}$ stand for statistical significance at the 1, 5 and $10 \%$ level respectively. 